\title{
Whirling in the late Permian: ancestral Gyrinidae show early radiation of beetles before Permian-Triassic mass extinction
}

\author{
Evgeny V. Yan ${ }^{1,2^{*}} \mathbb{D}$, Rolf G. Beutel ${ }^{1}$ and John F. Lawrence ${ }^{3}$
}

\begin{abstract}
Background: Gyrinidae are a charismatic group of highly specialized beetles, adapted for a unique lifestyle of swimming on the water surface. They prey on drowning insects and other small arthropods caught in the surface film. Studies based on morphological and molecular data suggest that gyrinids were the first branch splitting off in Adephaga, the second largest suborder of beetles. Despite its basal position within this lineage and a very peculiar morphology, earliest Gyrinidae were recorded not earlier than from the Upper Triassic.

Results: Tunguskagyrus. with the single species Tunguskagyrus planus is described from Late Permian deposits of the Anakit area in Middle Siberia. The genus is assigned to the stemgroup of Gyrinidae, thus shifting back the minimum age of this taxon considerably: Tunguskagyrus demonstrates 250 million years of evolutionary stability for a very specialized lifestyle, with a number of key apomorphies characteristic for these epineuston predators and scavengers, but also with some preserved ancestral features not found in extant members of the family. It also implies that major splitting events in this suborder and in crown group Coleoptera had already occurred in the Permian. Gyrinidae and especially aquatic groups of Dytiscoidea flourished in the Mesozoic (for example Coptoclavidae and Dytiscidae) and most survive until the present day, despite the dramatic "Great Dying" - Permian-Triassic mass extinction, which took place shortly (in geological terms) after the time when Tunguskagyrus lived.

Conclusions: Tunguskagyrus confirms a Permian origin of Adephaga, which was recently suggested by phylogenetic "tip-dating" analysis including both fossil and Recent gyrinids. This also confirms that main splitting events leading to the "modern" lineages of beetles took place before the Permian-Triassic mass extinction. Tunguskagyrus shows that Gyrinidae became adapted to swimming on the water surface long before Mesozoic invasions of the aquatic environment took place (Dytiscoidea). The Permian origin of Gyrinidae is consistent with a placement of this highly derived family as the sister group of all remaining adephagan groups, as suggested based on morphological features of larvae and adults and recent analyses of molecular data.
\end{abstract}

Keywords: Coleoptera, Adephaga, Gyrinidae, New taxon, Permian, Phylogeny, Early evolution

\section{Background}

The Permian-Triassic border 252 mya is an important threshold in the evolution of biota and Coleoptera in particular [1]. This time interval corresponds with the Permian-Triassic mass extinction, "when life nearly died", and $96 \%$ of marine together with $70 \%$ of terrestrial

\footnotetext{
*Correspondence: yan-e@mail.ru

'Institut für Spezielle Zoologie und Evolutionsbiologie, FSU, 07737 Jena, Germany

${ }^{2}$ Borissiak Paleontological Institute, Russian Academy of Sciences,

Profsoyuznaya ul. 123, Moscow 117997, Russia

Full list of author information is available at the end of the article
}

vertebrate species became extinct [2]. This event was also the only known example of mass extinction among insects, resulting in $57 \%$ of genera and $83 \%$ of insect species disappearing from the record [3]. Thus, it has been widely assumed, that representatives of the two most diverse groups of beetles, suborders Adephaga and Polyphaga, comprising $99 \%$ of all species, appeared in the Early Triassic at the earliest [4]. For a long time, studies of Permian-Triassic fossil beetles were hindered by insufficient paleontological material and its overall poor preservation, leaving wide space for scientific speculations. Even for a reliable placement of any fossil 
beetle within these two suborders, a complete body imprint is necessary with at least the ventral aspect preserved in some detail [5].

A Permian origin of adephagan beetles has been suggested [6], but was hitherto insufficiently documented. A basal position of whirligig beetles within Adephaga was proposed, with the Triassic Triadogyrus included as an early representative, and possibly also a controversial Permian larva described as Permosialis [7]. The discovery of a presumptive Permian species of Gyrinidae underlines a very long evolutionary history of this highly specialized group. It also implies very early splitting events in the suborder Adephaga and in crown group Coleoptera, notably a Permian appearance of Polyphaga. Tunguskagyrus gen. Nov. (Insecta: Coleoptera) with the single species T. planus sp. nov. is described from Late Permian deposits of the Anakit area in Middle Siberia. The genus is assigned to the stemgroup of Gyrinidae, thus shifting back the minimum age of this taxon considerably. Tunguskagyrus shows 250 myr of evolutionary stability for a very specialized lifestyle and key apomorphies of epineuston predators and scavengers, which are now characteristic features of Gyrinidae. The current finding clarifies the Paleozoic origin of a "modern" group of beetles, which along with other adephagan and polyphagan taxa flourished in the Mesozoic, and survive until the present day. Apparently the "Great Dying" - the PermianTriassic mass extinction - had only a limited impact on these groups. These dramatic events took place shortly (in geological terms) after the time when Tunguskagyrus lived.

\section{Results}

Systematic paleontology

INSECTA Linnaeus, 1758.

COLEOPTERA Linnaeus, 1758.

ADEPHAGA Schellenberg, 1806.

GYRINIDAE Latreille, 1810.

Tunguskagyrus gen. Nov.

Tunguskagyrus planus sp. nov.

\section{Etymology}

Generic name after Tunguska river and Gyrinus Geoffroy, 1762, type genus of the family Gyrinidae. The Latin specific name "planus" refers to the flattened body.

Material Holotype: PIN 5381/32, single specimen, counter print of the complete body impression with distal parts of legs all missing. Repository of Paleontological Institute, Russian Academy of Sciences.

Horizon and locality Upper Permian (Changhsingian), Anakit locality, Lebedevskian Horizon, correlated with Kedrovskian layers of the Maltsevo Formation, Krasnoyarsk region, Russia.
Diagnosis Short, semi-oval head with completely divided compound eyes, dorsal ocular subunits smaller than the lateral ones; short antennae with enlarged, paddle-shaped pedicel and stout proximal flagellomeres; body streamlined and drop-shaped; pronotum very short, transverse and curved; mesoventrite small, as long as mesocoxae, with small anteromedian groove; metacoxae transverse, without coxal plates; six completely exposed abdominal ventrites, the terminal one medially divided.

Description Medium sized, streamlined beetle without pronoto-elytral angle. Elytra very long in relation to head and prothorax. Drop-shaped in dorsal view, appearing flattened. Body length $10 \mathrm{~mm}$, maximum width, $5.1 \mathrm{~mm}$.

Head short, broader than long, rounded anteriorly; region posterior to compound eyes inserted into pronotum. Compound eyes completely divided into larger lateral subunit and smaller dorsal part, the latter in contact with anterior pronotal margin posteriorly; inner margin of lateral ocular subunit reinforced by thick carina; ocelli absent. Head capsule on dorsal side with paired oblique notches, containing antennal insertions. Anterolateral clypeal corners rounded, anterior margin straight; labrum indistinctly visible as very short anteriorly rounded structure. Antenna inserted laterally, anterior to lateral ocular subunit; scape almost spherical; pedicel paddle-shaped, large, distinctly protruding laterally; visible proximal flagellum compact, at least basal 3 flagellomeres short and wide. Mandibles triangular, robust and stout. Lateral lobes of mentum not recognizable, apparently very inconspicuous or absent.

Pronotum strongly transverse, very short, convex posteriorly, concave anteriorly; lateral margins nearly straight, strongly converging anteriorly; moderately sized protruding anterolateral pronotal angles present, apically rounded; pronotal epipleura wide anteriorly, strongly narrowing posteriorly; excavation for prolegs lacking. Propleura exposed, triangular, fairly large, with mesally directed, apically pointed posterior process partly closing procoxal cavities. Prosternum also short and transverse, but distinctly less wide than pronotum; with bead along anterior, posterior and lateral margins; anteriorly slightly concave; posterior edges straight, obliquely converging towards midline; prosternal process very short, almost absent; procoxae transverse, oblique; distal parts of all legs missing (fragment of protibia and metafemur visible, but very incomplete preservation makes them negligible). Elytra wedge-shaped, with rounded apices, finely edged; posteriorly not truncated; surface smooth, without recognizable striae or other sculpture; elytral epipleura anteriorly broad, converging towards elytral apex, lacking excavation for prolegs. Mesoventrite small, with anterior procoxal rests and very small anteromedian groove, 
lacking transverse suture; posteromedially overlapped by anteromedian process of metaventrite; lateral edges strongly rounded; mesanepisternum triangular, relatively small; mesepimeron fairly wide, very slightly curved, with subparallel margins, slightly widening laterally; mesally forming part of closure of mesocoxal cavities; mesocoxae separated medially, roughly triangular, with anterolateral notch probably fitting with mesotrochantin. Metaventrite large, slightly converging anteriorly, with semicircular excavations for mesocoxae and between them a large triangular anteromedian process; posteromedially with triangular pointed process between mesal metacoxal bases; discrimen not visible; transverse ridge delimiting katepisternum reaches lateral margin of ventrite, mesally converging towards anterior coxal margin. Exposed part of metanepisternum large, triangular, reaching mesocoxal cavity only with narrow mesal apex; metepimeron not recognizable. Metatrochantin not exposed. Metacoxae large, transverse, distinctly reaching beyond posterolateral margin of ventrite; anteriorly not extended, not plate-like; mesally adjacent but mesal walls not fused or connected; plate-like duplicatures, i.e. metacoxal plates absent; distinct sinuate transverse edge likely fitting with anterior metafemoral edge; median coxal lamellae distinct, posteriorly rounded; posterior coxal edge oblique, lateral edge slightly shorter than maximum length close to midline.

Abdomen oval, with six loosely connected ventrites; first completely exposed ventrite corresponds to sternite III, with short median process fitting between mesal coxal lamellae; sternite II only visible laterally as triangular sclerite; sternites III-V almost equally broad, V slightly narrower than III and IV, all three with straight or nearly straight posterior margin. Posterior part of abdomen strongly tapering, with slightly rounded lateral edges and distinctly concave posterior margins; terminal ventrite likely represented by medially divided gonocoxosternum VIII; separation along midline distinct posteriorly but not visible on anterior part. Paired, flat female gonocoxae visible posterior to terminal ventrite; with rounded apical part, reaching elytral apices posteriorly.

\section{Discussion}

\section{Phylogenetic affinities of Tunguskagyrus}

Tunguskagyrus is a Permian beetle with a striking appearance, differing profoundly from other fossils of the period, notably the taxa assigned to the stem group of Coleoptera by Beutel [4, 5], i.e. Protocoleoptera, Permocupedidae, and Rhombocoleidae. The entire set of features is clearly incompatible with a placement in the "ancestral" Archostemata s.str. [5] or s.l. [8]. This includes the oval body shape, the smooth surface, evenly sclerotized elytra, the lack of a transverse suture of the mesoventrite, the absence of exposed metatrochantins, a metanepisternum not forming a distinct part of the closure of the mesocoxal cavities (only very narrow contact), and the presence of six fully exposed abdominal ventrites (Figs. 1a, 2a). In contrast to Tunguskagyrus, the Mesozoic archostematan family Schizophoridae, which was possibly aquatic and had a streamlined body and largely smooth cuticular surface, shows the typical archostematan configuration of the ventral thoracic and abdominal sclerites $[5,8]$. This makes a close relationship between the two taxa very unlikely. Moreover, schizophorids do not show any of the specialized cephalic features characterizing the genus described here.

The distinctly exposed propleuron (Figs. 1a, 2a,b) clearly excludes a placement in the megadiverse Polyphaga e.g. [9], according to different studies the sister group of the remaining three suborders e.g. 1, [10]. The comparatively large size, mesocoxae inserted relatively close to each other, and a distinct separation of the meso- and metaventrite are incompatible with a placement in the small suborder Myxophaga, a group characterized by small or very small body size with most species living in hygropetric habitats e.g. [11]. The pterothoracic ventrites are always firmly connected or fused in Myxophaga and also in almost all families of Polyphaga (excl. Scirtoidea and Leiodidae [12]). In contrast, this condition is unknown in Adephaga and also in Archostemata [5, 12].

A large triangular anteromedian process of the metaventrite, as it is found in Tunguskagyrus, is a condition typical for beetles of the suborder Adephaga (Fig. 5). This process articulates with the posteromedian part of the mesoventrite [13]. An additional adephagan feature is the large size and transverse shape of the metacoxae, which reach beyond the lateral border of the metaventrite. This feature is secondarily modified in Carabidae, probably constituting autapomorphies of this speciesrich terrestrial family [13].

Derived features of the head clearly suggest a placement of Tunguskagyrus in the family Gyrinidae (Figs. 1b, $2 b)$. The head in its general shape is similar to what is found in extant and extinct members of this group e.g. [14-16]. A conspicuous shared derived feature of Tunguskagyrus and extant Gyrinidae is the complete subdivision of the compound eyes. Another unusual synapomorphy is the modification of the antennal pedicellus as a paddle-shaped structure, presumably set with setae and used for detecting movements of the water surface [17]. An additional antennal apomorphy is the compactness of the flagellum, with stout flagellomeres and apparently hardly reaching beyond the hind margin of the head. Other potential synapomorphies are the short prosternal process, exposed and at least partly separated gonocoxosternites VIII, and exposed flattened gonocoxae VIII see [14, 18, 19] (Figs. 1a, 2a). 

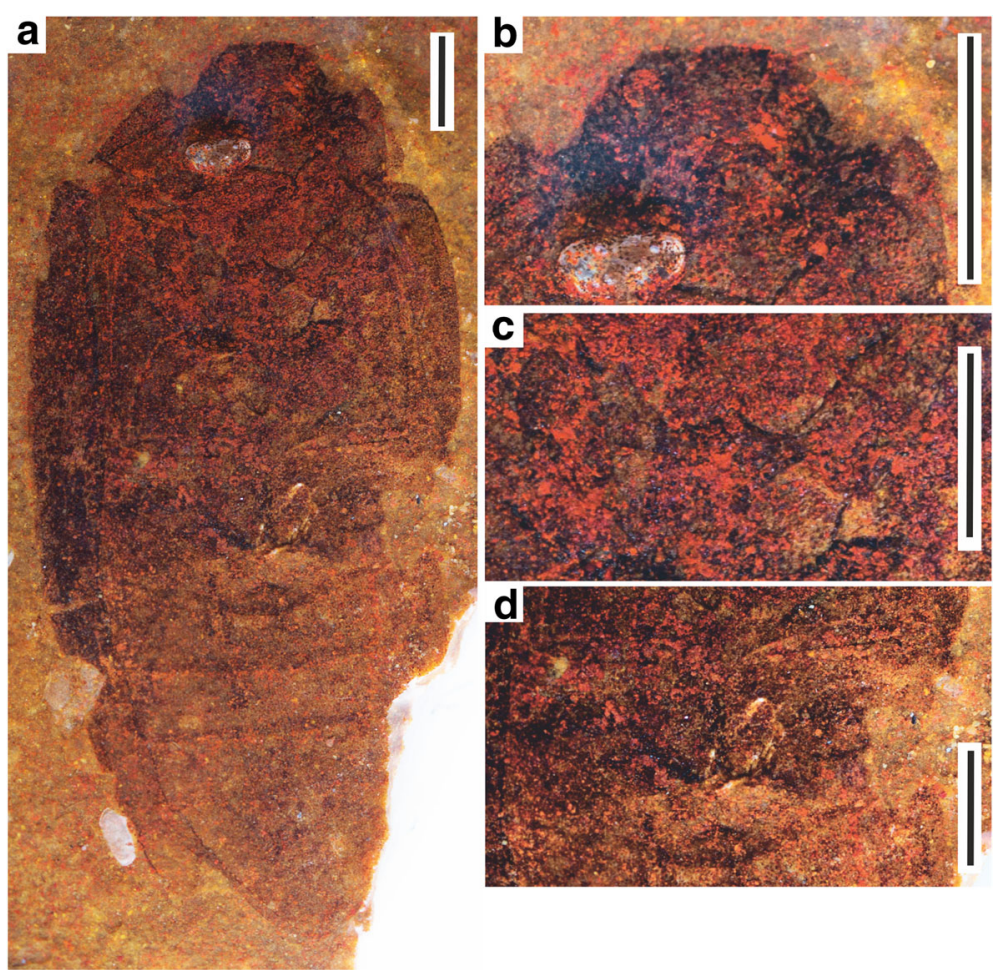

Fig. 1 Tunguskagyrus planus sp. nov., Habitus. a Photograph of the holotype 5381/32. b Details of head. c Mesoventrite and midcoxae. d Metacoxae and the base of abdomen. Scalebars $=1 \mathrm{~mm}$

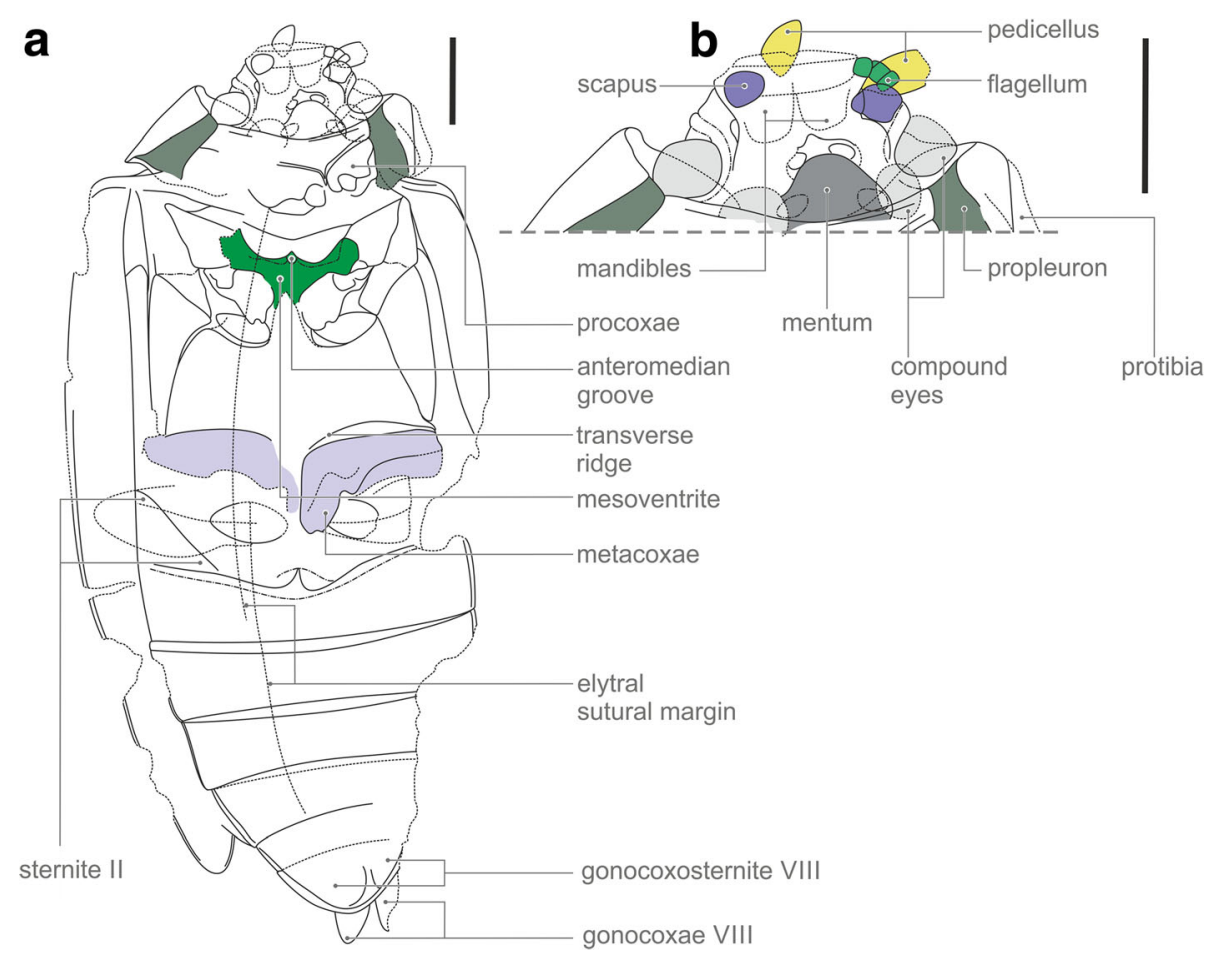

Fig. 2 Tunguskagyrus planus sp. nov. a Interpretative habitual drawing. b Interpretation of head structure. Scalebars =1 mm 
Several characteristics of the new genus differ from Mesozoic, Cenozoic and extant Gyrinidae [14]. The most striking difference is the small mesoventrite, in contrast to a flat and extensive sclerite in extant Gyrinidae including the ancestral Spanglerogyrus [20]. The mesoventrite of Tunguskagyrus also differs from the condition in all other adephagan groups including basal lineages of Carabidae [13]. As in other Gyrinidae, it lacks a large hexagonal groove separated from the anterior edge and usually articulating with a well-developed prosternal process [e.g. [13, 21, 22]. However, in contrast to all extant species of the family a small median groove is present at the anterior margin of the sclerite (Fig. 5). The small size of the mesoventrite of Tunguskagyrus implies that this species lacked a large mesothoracic sternotrochanteral muscle M. [51], which creates the main propulsive force of the middle leg in extant Gyrinidae $[18,20]$. The presence of a nearly complete transverse ridge of the metaventrite is a symplesiomorphy shared with Spanglerogyrus and the non-dytiscoid adephagan groups including Haliplidae [20, 21] and the extinct Triaplidae [23, 24] (Fig. 5). The metacoxae of Tunguskagyrus are moderately sized compared to the plate-like extensive ones of extant Gyrinini and Orectochilini [14, 18, 20], without an anterolaterally extended anterior margin. They are more similar to those of Spanglerogyrus [20], even though slightly longer at their lateral edge, or also to the metacoxae of Enhydrini e.g. [14] (but compared to these distinctly shorter close to the midline). The moderate size of the metaxocae indicates a smaller size of the coxotrochanteral muscles, which are very large in extant Gyrininae [18, 20, 25] and play an important role in creating the propulsive force of the hindlegs.

The origin of Gyrinidae was estimated to be Late Permian or earlier, the divergence of Spanglerogyrinae from the remaining genera was dated as Triassic, and the divergence time of Heterogyrinae (Heterogyrus) from Gyrininae as Late Triassic or Early Jurassic [7]. Considering the available evidence, the most plausible conclusion is to place Tunguskagyrus as the sister group of a clade comprising crown group Gyrinidae (including Spanglerogyrus) and very likely also Triadogyrus and the other Mesozoic members of the family. This monophyletic unit is mainly characterized by an extensive and flat mesoventrite, and correlated with this feature a large mesothoracic sterno-trochanteral muscle is present in extant Gyrininae and Heterogyrinae [20]. The condition of the distal parts of the legs of Tunguskagyrus is not documented, but this placement implies that they were not short and paddle-like, as in extant Heterogyrinae and Gyrininae [14, 15, 18, 26], an interpretation also compatible with the comparatively small mesoventrite and metacoxae. The assignment of Tunguskagyrus to the stemgroup of Gyrinidae implies that the dorsal eyes were independently reduced in size and shifted dorsad (Figs. 1b, 2b), similar to the condition in Gyrininae $[15,16]$. Similarly, the extremely shortened prosternal process in Tunguskagyrus and Orectochilini [14] must be a result of parallel evolution. A feature differing from the typical adephagan condition is the lack of lateral lobes of the mentum, which are generally welldeveloped in extant Adephaga e.g. [22] and even enlarged in Heterogyrinae and Gyrininae e.g. [15, 16]. Nevertheless, a placement in the suborder appears likely, even without considering the obvious structural affinities with extant Gyrinidae.

Gyrinidae, the whirligig beetles, are adapted for a unique lifestyle of swimming in the water surface film [27-29], an unusual habitat sometimes referred to as a "world of the dead and the dying" [29] (Fig. 4). Morphological and recent molecular studies suggest that the family was the first branch splitting off in Adephaga [1, 4, 30,31], the second largest subgroup of Coleoptera. Despite its basal position within this suborder (sister to all remaining adephagan families) and a very peculiar morphology usually recognizable in the fossil state, until now the earliest extinct Gyrinidae were recorded from Late Triassic deposits of Ukraine [23, 30]. Thus, Tunguskagyrus adds more than 60 million years to the minimum age of the family.

\section{Early evolution of Gyrinidae}

Ancestral Permian beetles included in the stem group of Coleoptera (Archostemata s.l.) [8] where very likely associated with wood, with many preserved coleopteran groundplan features, including a tuberculate body surface, broadly closed procoxal cavities, a transverse ridge on the mesoventrite, elytra with a characteristic pattern of window-punctures, an exposed transverse metatrochantin, and five exposed abdominal ventrites, the last one sternite VII, and completely invaginated structures of the following segments, except for a process addressed as ovipositor in the protocoleopteran families Tshecardocoleidae and Moravocoleidae [8, 32].

In striking contrast to this ancestral life style and structural configuration, Tunguskagyrus apparently represents a very early invasion of aquatic habitats, with a complex set of adaptations. This includes the streamlined and probably distinctly flattened body, conspicuous modifications of the head, including specifically modified antennae and subdivided compound eyes, and exposed terminal abdominal gonocoxosterna and gonocoxae, the latter probably functioning as steering organs [18]. It is apparent that Tunguskagyrus is part of a shifting pattern of late Permian insect communities, with forms much more resembling Mesozoic species than stem group coleopterans (Archostemata s.l.), which were still dominant elements of the beetle diversity in the late Paleozoic e.g. $[8,33]$. 
Tunguskagyrus differs distinctly from the aquatic Triaplidae, another extinct adephagan group from the Early Mesozoic (or possibly Late Permian) [23, 30]. This family included medium-sized beetles with an elongated, flattened body, hypognathous head, and large metacoxal plates resembling those of extant Haliplidae [34]. Triaplidae, considered as the first aquatic group of Adephaga [23], showed only moderate adaptations to aquatic habits compared to Tunguskagyrus: a stream-lined body and possibly an additional air-storage space under the extensive metacoxal plates e.g. [34]. Apparently lacking adaptations for rapid swimming, triaplids are similar to the extinct archostematan family Schizophoridae in different plesiomorphic features. A lifestyle similar to modern Dryopidae (Coleoptera; Polyphaga) was proposed for members of the small extinct family, with the beetles hanging down from the underside of the water surface film and scraping algae from it $[6,35]$, similar to feeding habits of the extant polyphagan family Spercheidae (Hydrophiloidea) [36]. The systematic placement of Triaplidae is still unclear [30]. An assignment of Triaplus sibiricus to the advanced Dytiscoidea [6] is not supported by convincing apomorphies see e.g. [30].

An entire suite of features of different body parts of "modern" Gyrinidae is related to locomotion in the aquatic environment [18, 37], notably to swimming in the surface film. This includes an enlarged and flat mesoventrite, and a shortened metaventrite resulting from enlarged meso- and metacoxae, which contain large coxo-trochanteral muscles [18]. These features have been observed in the Middle Jurassic Angarogyrus, but in clear contrast the plesiomorphic states preserved in Tunguskagyrus, bringing this genus closer to the presumptive groundplan of the suborder Adephaga. A mesoventrite of intermediate size is found in the second oldest gyrinid Triadogyrus sternalis: the sclerite is definitely larger than that of Tunguskagyrus (Fig. 5), but still quite small in comparison to the mesoventrite of later Mesozoic and Cenozoic fossils assigned to Gyrinidae.

The comparatively small metacoxae of Tunguskagyrus indicate smaller attachment areas and smaller size of the intrinsic muscle functioning as extensor (M87) after the backward stroke of the hindlegs (M84, M86) [18]. This suggests a limited ability to swim and maneuver fast on or under the water surface in comparison with extant Gyrinidae e.g. [18, 37]. Unmodified mesocoxae also imply that the middle legs were not or only occasionally used for swimming, as it is the case in "modern" Dytiscidae [38]. A noteworthy plesiomorphic feature of the mesoventrite of Tunguskagyrus is the presence of an anteromedian pit, which is adapted for receiving the prosternal intercoxal process in other non-adephagan groups of beetles (process strongly reduced in Tunguskagyrus). This character is absent in all recent Gyrinidae, but present in almost all fossil representatives of the family, visible as an anteromedial notch (Fig. 5).

Extant Gyrinidae are characterized by a very unusual flight apparatus $[18,22]$. Unfortunately, no wings are preserved or other structures allowing conclusions on the flight capacity. However, as flightlessness is apparently a rare exception in the family e.g. $[18,20,28]$ and certainly not part of the groundplan, it is likely that Tunguskagyrus possessed well developed wings and other elements of the flight apparatus.

\section{Conclusions}

Tunguskagyrus confirms a Permian origin of Adephaga, which was hitherto not well supported by published evidence, even though the presence of Trachypachidae and Triaplidae in this period was noted. It is conceivable that a Permian larva described as Permosialis also belongs to Gyrinidae and not to Megaloptera. However, this requires a reinvestigation and redescription of the type material [30]. The new genus documents a very early specialization strikingly different from the life habits of stem group Coleoptera e.g. [4, 5, 8, 39], with adaptations to moving on the water surface (Fig. 4) and probably collecting small arthropods caught in the surface film. This may have taken place at about the same time as the switch to an aquatic lifestyle in Triaplidae, which strongly differ in their morphology and very likely also in their life habits. These habitat shifts obviously predated the Mesozoic invasions of the aquatic environment, accomplished by Haliplidae and Dytiscoidea, by members of the non-monophyletic coptoclavids [30], and by hydrophiloids [e.g. Amphiops [40]] and other groups of Polyphaga [4, 41, 42]. Compound eyes adapted to living on the water surface is a rare specialization within beetles (see coptoclavids e.g. [30], Amphiops [40]). An interpretation as a stepping-stone towards a fully submerged aquatic life was suggested [7, 43] but appears less likely. This would imply secondary fusion of the ocular subunits in subaquatic groups.

Tunguskagyrus does not contribute to a clarification of the subordinal relationships in Coleoptera, which are still controversial e.g. [1, 10, 12, 32, 39, 42, 44]. Likewise, it does not provide direct evidence for the interrelationships of the adephagan families. However, the documented Permian origin of Gyrinidae is consistent with a placement of this highly specialized family as the sister group of all the remaining groups of Adephaga, i.e. Haliplidae (possibly closely related with Triaplidae), Dytiscoidea (including a subgroup of Coptoclavidae [30]) and Geadephaga (Trachypachidae and Carabidae). This was suggested based on morphological features of larvae and adults [19, 30], and recent analyses of molecular data also yielded a basal placement of the family [31]. 

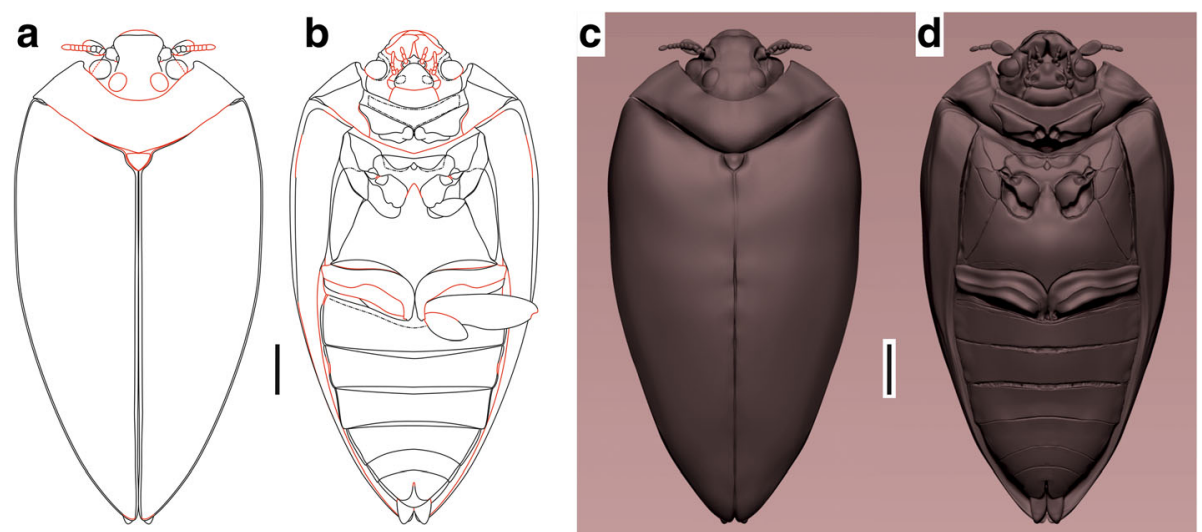

Fig. 3 Tunguskagyrus planus sp. nov., Habitual reconstructions. a-b 2D vector reconstruction. c-d 3D reconstruction. Scalebars $=1 \mathrm{~mm}$

Even though our morphological reconstruction of Tunguskagyrus is incomplete due to partial preservation of the type material, it provides a fascinating glimpse of a very early aquatic specialization, very different from the life style of most Permian beetles, underlining a beginning shift in the composition of insect communities before the Permian - Triassic event of mass extinction. Future findings of more complete specimens may confirm (or falsify) the interpretations presented here and further elucidate the life habits of an intriguing Permian beetle species.

\section{Methods}

Specimen of Tunguskagyrus was collected by Dr. Sadovnikov G.N. under the programme "Geological and Paleontological studies of Siberia", in compliance with all sample-collecting procedures, in 1963. Locality description: Anakit ("Anakit" is a group of three closely spaced localities), Lebedevskian Horizon, Krasnoyarsk region, left bank of the river Nizhnyaya Tunguska, right below the mouth of the Anakit river, Lebedevskian Horizon is correlated with Kedrovskian layers of the Maltsevo Formation in the Tunguska basin [45]. The age of Lebedevskian Horizon was identified as either Permian [46] or Triassic [47]. In later biostratigraphical studies Lebedevskian Horizon is attributed to Changhsingian (252-254 myr) of uppermost Permian [48, 49].

The Anakit locality represents a combination of stagnant and lotic basins during Vyatkian time interval [48], which yields abundant paleontological material including conchostracans [50], bivalves [51], insects [52], amphibians [53] and plants [48]. It seems that intensified of volcanism during the Vyatkian Age did not result in a suppressing effect on the biotas of the basins: only two bivalve species became extinct, while the integral diversity of the assemblages very distinctly increased. The diversity of the Vyatkian leaf flora increased even more in comparison to the preceding Vishkilian Age [48].
The specimen of Tunguskagyrus was examined dry using microscopes Leica M165C and Zeiss Stemi 2000. The photographs were taken with Leica DFC 425 and Keyence VHX - J20 digital cameras. Line drawings were prepared based on photographs using image-editing software: CorelDRAW X8 and Adobe Photoshop CS. Drawing conventions are as follows: solid line, distinct margin; dashed, indistinct margin and structures overlapping each other; dashed and dotted, fold; dark grey, posteriorly open procoxal cavities. In the $2 \mathrm{D}$ reconstructions (Fig. 3a, b and Fig. 4 [Tunguskagyrus]) red lines are reconstructed parts, black lines characters restored after type material. Images in Fig. 5 were redrawn after different sources with minor modifications: Spanglerogyrus after [20], Enhydrus after [14], Orectogyrus after [54], Gyrinus after [55], Mesodineutes, Cretotortor, Baissogyrus Mesogyrus striatus and M. antiquus after [56], and

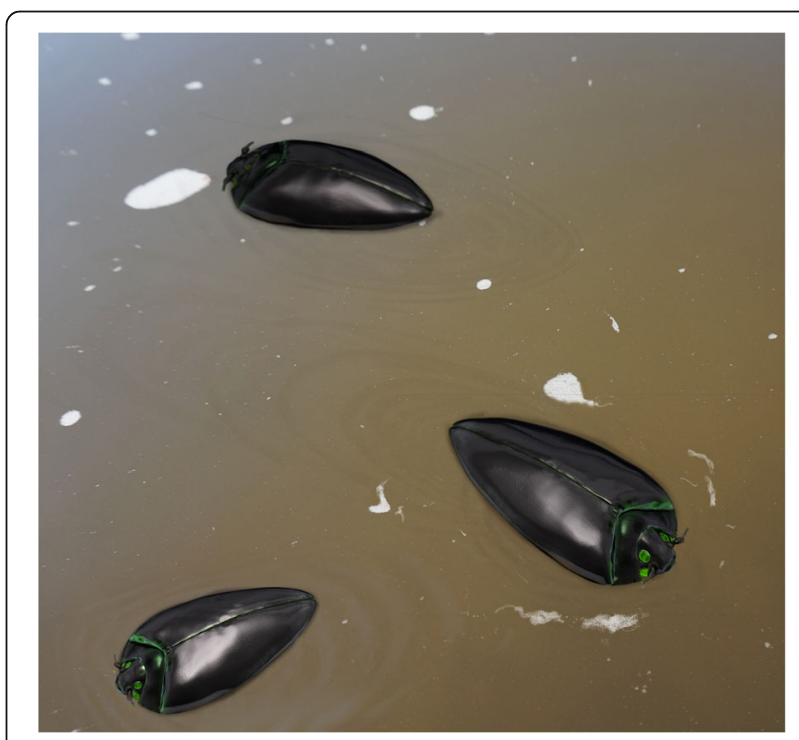

Fig. 4 Tunguskagyrus planus sp. nov. Artistic reconstruction 


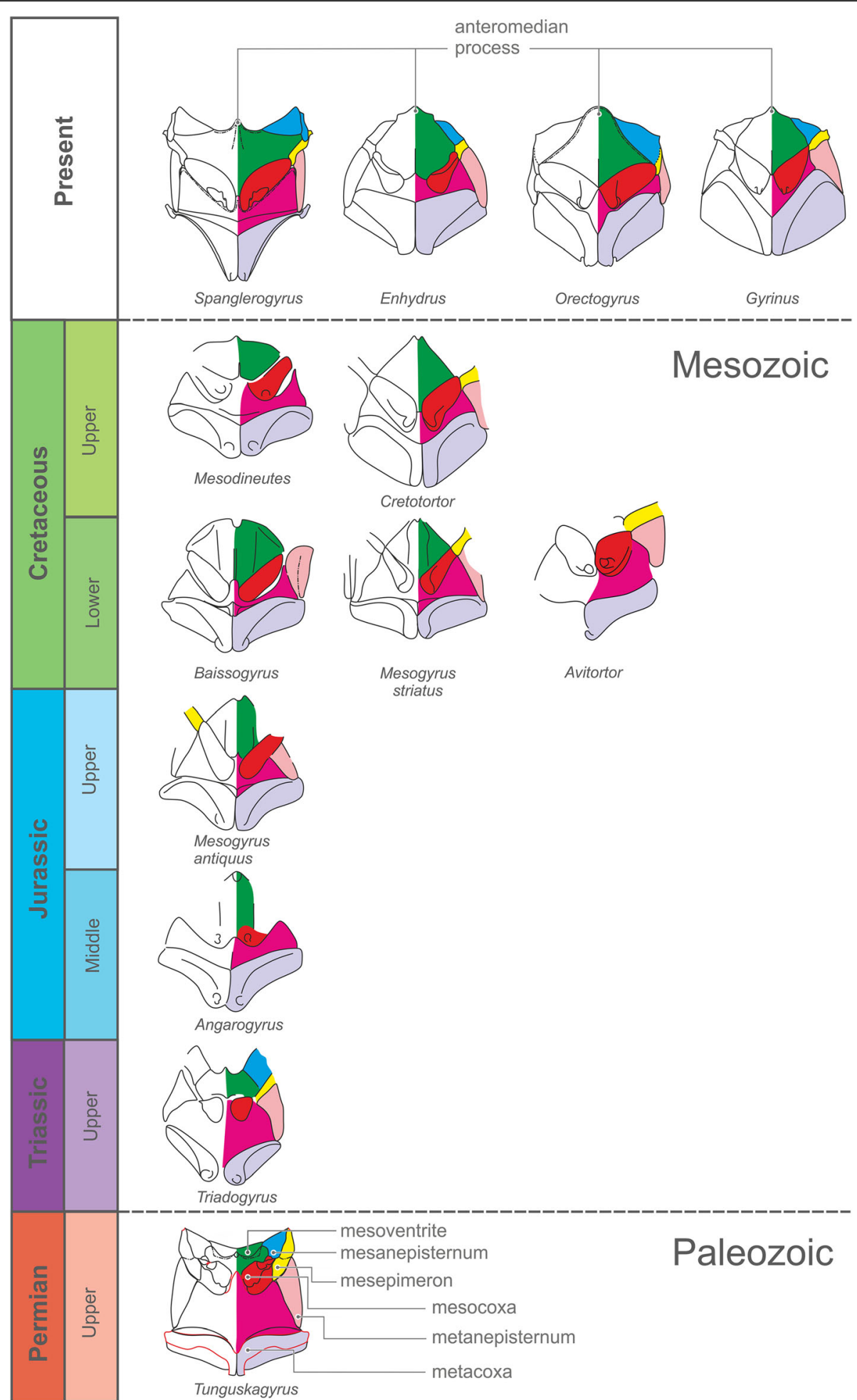

Fig. 5 Details of meso- and metathoracic organization in some extinct and Recent Gyrinidae

Avitortor, Angarogyrus and Triadogyrus after [23]. Gyrinids listed in [7] but not included here are either represented by isolated elytra, or need to be reexamined.
The following measurements were recorded for Tunguskagyrus (depending on the state of preservation): total body length; maximum body width; length and width of elytra, head, pronotum, abdomen. 
Archostemata (s. str.) is used for the suborder in the sense of Beutel [4] and Beutel and Haas [12], with the majority of extinct Permian families regarded as stem group Coleoptera. Archostemata s.l. refers to the concept of Ponomarenko [8] with Archostemata also including Permian stemgroup beetles (e.g., $\uparrow$ Tshecardocoleidae, †Permocupedidae).

\section{Abbreviations \\ ACT: Australian capital territory; CSIRO: Commonwealth Scientific and Industrial Research, Canberra, Australia; FSU: Friedrich Schiller University, Institute of Systematic Zoology and Evolutionary Biology, Jena, Thuringia, Germany; GPO: General Post Office; M84: Muscle noto-trochanteralis; M86: Muscle coxa-trochanteralis medialis; M87: Muscle coxa-trochanteralis lateralis; mya: Million years ago; myr: Million years; PIN: Paleontological Institute, Russian Academy of Sciences; QLD: Queensland; RAS: Russian Academy of Sciences}

\section{Acknowledgments}

We are grateful to Dr. Hans Pohl of the Institut für Spezielle Zoologie und Evolutionsbiologie, FSU Jena, for making high-quality photographs of Tunguskagyrus. Prof. Dr. Alexander Ponomarenko of Borissiak Paleontological Institute and Dr. A.A. Prokin of Papanin Institute of Inland Waters, for valuable discussions during manuscript preparation

\section{Fundings}

This research was supported by Alexander von Humboldt research foundation (YEV) providing finances for illustrative software (CorelDraw, ZBrush) and supporting YEV during his stay in FSU Jena; the Russian Foundation for Basic Research (16-04-01498) providing financial support for sending fossil material to FSU Jena and storing in PIN RAS It was also linked with studies on extant Gyrinidae carried out in the framework of the Big4 Project. Accordingly, financial support for publication costs was provided by the European Union's Horizon 2020 research and innovation programme under the Marie Sklodowska-Curie grant agreement No. 642241. This is gratefully acknowledged. Financial support by the DFG (BE 1789/13-1) is also gratefully acknowledged. This was used for microtome sectioning of extant potentially related species.

\section{Availability of data and materials}

Tunguskagyrus is deposited in Moscow Paleontological Institute, Russian Academy of Sciences (PIN RAS) in compliance with national and international rules of scientific material storing.

The data used and/or analyzed during the current study are available from the corresponding author on reasonable request.

Specimens of extant Heterogyrus milloti Legros and microtome sections series are kept in the research collection of R.G.B. at the Phyletisches Museum Jena. This material will be made available upon request.

\section{Author's contributions}

E.Y. and R.G.B. prepared the manuscript and figures, made taxonomical identification. R.G.B. provided specimens of recent Gyrinidae and interpreted them and evaluated taxonomic affinities and early evolution of Gyrinidae parts of the Discussion section. E.Y. prepared 3D models and render images 3 and 4. J.L. contributed to the Discussion, checked the interpretation and presence of characters in the Systematic paleontology section, improved the manuscript linguistically, and made his exceptionally broad and profound knowledge of Coleoptera available. All authors contributed to and approved the final version of the paper.

\section{Ethics approval and consent to participate}

Not Applicable.

\section{Consent for publication}

Not applicable.

\section{Competing interests}

The authors declare that they have no competing interests.

\section{Publisher's Note}

Springer Nature remains neutral with regard to jurisdictional claims in published maps and institutional affiliations.

\section{Author details}

${ }^{1}$ Institut für Spezielle Zoologie und Evolutionsbiologie, FSU, 07737 Jena, Germany. ${ }^{2}$ Borissiak Paleontological Institute, Russian Academy of Sciences, Profsoyuznaya ul. 123, Moscow 117997, Russia. ${ }^{3}$ Australian National Insect Collection, CSIRO GPO, Box 1700, ACT 2601, Australia and 61 Glenbar Rd., The Palms, QLD, Canberra 4570, Australia.

Received: 16 November 2017 Accepted: 15 February 2018

Published online: 16 March 2018

\section{References}

1. McKenna DD, Wild AL, Kanda K, Bellamy CL, Beutel RG, Caterino MS, Farnum CW, Hawks DC, Ivie MA, Jameson ML, et al. The beetle tree of life reveals Coleoptera survived end Permian mass extinction to diversify during the cretaceous terrestrial revolution. Syst Entomol. 2015;40:835-80.

2. Benton MJ. When life nearly died: the greatest mass extinction of all time. New York: Thames \& Hudson; 2005

3. Rasnitsyn AP. When life did not intend to die. Priroda. 2012;9:39-48.

4. Beutel RG. Über Phylogenese und Evolution der Coleoptera (Insecta), insbesondere der Adephaga. Verh Naturwiss Ver Hamb NF. 1997:31:1-164.

5. Beutel RG, Ge SQ, Hörnschemeyer T. On the head morphology of Tetraphalerus, the phylogeny of Archostemata and the basal branching events in Coleoptera. Cladistics. 2008;24:270-98.

6. Ponomarenko AG, Prokin AA. Review of paleontological data on the evolution of aquatic Coleoptera. Paleontol J. 2015;49:1383-412.

7. Gustafson GT, Prokin AA, Bukontaite R, Bergsten J, Miller KB. Tip-dated phylogeny of whirling beetles reveals ancient lineage surviving on Madagascar. Sci Rep. 2017; https://doi.org/10.1038/s41598-017-08403-1.

8. Ponomarenko AG. Historical development of archostematan beetles. $\mathrm{Tr}$ Palaeontol Inst Akad Nauk SSSR. 1969;125:1-237.

9. Yan E, Ponomarenko AG, Beutel RG. Peltosynidae - a new beetle family from the middle-late Triassic of Kirghyzia - its affinities to Polyphaga (Insecta, Coleoptera) and the groundplan of the megadiverse suborder. I Syst Palaeont. 2017; https://doi.org/10.1080/14772019.2017.1313789.

10. Misof M, Liu S, Meusemann K, Peters RS, Donath A, Mayer C, Frandsen PB, Ware J, Flouri T, Beutel RG, et al. Phylogenomics resolves the timing and pattern of insect evolution. Science. 2014;346:763-7.

11. Beutel RG. 6. Myxophaga Crowson, 1965. In: Beutel RG, Leschen RAB editors. Handbook of zoology, Vol. IV Arthropoda: Insecta. Part 38. Coleoptera, Vol. 1, 2nd edition: Morphology and systematics (Archostemata, Adephaga, Myxophaga, Polyphaga (partim). Berlin, New York: Walter De Gruyter; 2016. p. 63-65.

12. Beutel RG, Haas F. Phylogenetic relationships of the suborders of Coleoptera (Insecta). Cladistics. 2000:16:103-41.

13. Beutel RG. Phylogenetic analysis of thoracic structures of Carabidae (Coleoptera). Z Zool Syst Evolution. 1992;30:53-74.

14. Hatch MH. The morphology of Gyrinidae. Pap Mich Acad Sci Arts Lett. 1926; 7:311-50.

15. Beutel RG. The head of Spanglerogyrus albiventris Folkerts (Coleoptera: Gyrinidae). Contribution towards clarification of the phylogeny of Gyrinidae and Adephaga. Zool Jb Anat. 1989:118:431-61.

16. Beutel RG, Yan E, Richter A, Büsse S, Miller KB, Yavorskaya M, Wipfler B. The head of Heterogyrus milloti (Coleoptera: Gyrinidae) and its phylogenetic implications. Arthr Syst Phyl. 2017;75:261-80.

17. Bendele H. Mechanosensory cues control chasing behavior of whirligig beetles (Coleoptera, Gyrinidae). J Comp Phys. 1986;158:405-11.

18. Larsén $\mathrm{O}$. On the morphology and function of locomotor organs of the Gyrinidae and other Coleoptera. Opusc Entomol. 1966;30(Suppl):1-241.

19. Beutel RG, Roughley RE. On the systematic position of the family Gyrinidae (Coleoptera: Adephaga). Z zool Syst Evolutionsforsch. 1988;26:380-400.

20. Beutel RG. Phylogenetic analysis of the family Gyrinidae (Coleoptera) based on meso- and metathoracic characters. Quaest entomol. 1990;26:163-91.

21. Beutel RG, Belkaceme T. Comparative studies on the metathorax of Hydradephaga and Trachypachidae. Entomol Basiliensia. 1986;11:221-9.

22. Belkaceme T. Skelet und Muskulatur des Kopfes und Thorax von Noterus laevis Sturm. Ein Beitrag zur Morphologie und Phylogenie der Noteridae (Coleoptera: Adephaga). Stuttg Beitr Naturk Ser A. 1991;462:1-94. 
23. Arnoldi LV, Zherikin W, Nikritin LM, Ponomarenko AG. Mesozoic Coleoptera. Washington D.C.: Smith Inst Lib and Nat Sci Found; 1992.

24. Ponomarenko AG. The historical development of Coleoptera. Tr Paleontol Inst Akad Nauk SSSR. 1983;167:1-47.

25. Nachtigall W. Funktionelle Morphologie, Kinematik und Hydromechanik des Ruderapparates von Gyrinus. Z vergl Phys. 1961:45:193-226.

26. Gustafson GT, Bergsten J, Ranarilalatiana T, Randriamihaja JH, Miller K. The morphology and behavior of the endemic Malagasy whirligig beetle Heterogyrus milloti Legros, 1953 (Coleoptera: Gyrinidae: Heterogyrinae). Coleopt Bull. 2017;71:315-28.

27. Bott RH. Beitrag zur Kenntnis von Gyrinus natator substriatus Steph. Z Morph Ökol Tiere. 1928;10:207-306.

28. Ochs G. Zur Ethökologie der Taumelkäfer (Col., Gyrinoidea). Arch Hydrobiol. 1969;35 Suppl:373-410.

29. Omer-Cooper J. Notes on the Gyrinidae. Arch Hydrobiol i Ryb. 1934;8:1-26

30. Beutel RG, Wang B, Tan JJ, Ge SQ, Ren D, Yang XK. On the phylogeny and evolution of Mesozoic and extant lineages of Adephaga (Coleoptera, Insecta). Cladistics. 2013;29:147-65.

31. Baca SM, Alana A, Gustafson GT, Short AEZ. Ultraconserved elements show utility in phylogenetic inference of Adephaga (Coleoptera) and suggest paraphyly of Hydradephega. Syst Entomol. 2017; https://doi.org/10.1111/ syen.12244.

32. Kukalová-Peck J, Beutel RGI. The carboniferous †Adiphlebia lacoana really the "oldest beetle"? Critical reassessment and description of a new Permian beetle family. Eur J Entomol. 2012;109:633-45.

33. Rasnitsyn AP, Aristov DS, Rasnitsyn DA. 3.1. Insects of the Permian and early Triassic (Urzhumian-Olenekian ages) and the problem of the Permian-Triassic biodiversity crisis. In: Aristov DS, editor. Fossil insects of the middle and upper Permian of European Russia. Moscow: Paleontol J. 2013;47(7):793-823

34. Belkaceme T. Skelet und Muskulatur der Hinterhüfte von Haliplus lineatocollis Mrsh. (Haliplidae, Coleoptera). Stuttg Beitr Naturk Ser A. 1986; 393:1-12.

35. Ponomarenko AG. Beetles (Insecta, Coleoptera) of the late Permian and early Triassic. Palaeontol J. 2004;38:185-96.

36. Beutel RG, Anton E, Bernhard D. Head structures of adult Spercheus: their function and possible significance to staphyliniform phylogeny. Ann Zoologici. 2001;51(4):473-84.

37. Heinrich B, Vogt FD. Aggregation and foraging behavior of whirligig beetles (Gyrinidae). Behav Ecol and Sociobiology. 1980;7:179-186.

38. Nachtigall W. Über Kinematik, Dynamik und Energetik des Schwimmens einheimischer Dytisciden. Zugleich ein Beitrag zur Anwendung von Kurzzeiphotographie und Hochfrequenzkinematographie auf biologische Probleme. Z vergl Phys. 1960;43:48-118.

39. Friedrich F, Farrell BD, Beutel RG. The thoracic morphology of Archostemata and the relationships of the extant suborders of Coleoptera (Hexapoda). Cladistics. 2009;25:1-37.

40. Fenglong JA. Revisional study of the Chinese species of Amphiops Erichson (Coleoptera, Hydrophilidae, Chaetarthriini). J Nat Hist. 2014; https://doi.org/ 10.1080/00222933.2013.861938

41. Crowson RA. The evolutionary history of Coleoptera, as documented by fossil and comparative evidence. Atti del X Cong Naz Ital Entomol Sass. 1975:47-90.

42. Crowson RA. The biology of Coleoptera. London: Academic Press; 1981.

43. Ribera I, Beutel RG, Balke M, Vogler AP. Discovery of Aspidytidae, a new family of aquatic Coleoptera. Proc R Soc. 2002;269:2351-6.

44. Shull VL, Vogler AP, Baker DR, Maddison DR, Hammond PM. Sequence alignment of $18 \mathrm{~S}$ ribosomal RNA and the basal relationships of adephagan beetles: evidence for monophyly of aquatic families and the placement of Trachypachidae. Syst Biol. 2001;50:945-69.

45. Mogutcheva NK, Krugovykh W. New data on the stratigraphic chart for Triassic deposits in the Tunguska syneclise and Kuznetsk basin. Stratigr Geol Corr. 2009;17(5):510-8.

46. Sadovnikov GN, Orlova EF. Taimyr stage - the terminal stage of the Permian. Rep RAS. 1994;338(5):658-61.

47. Kozur HW, Weems RE. Detailed correlation and age of continental late Changhsingian and earliest Triassic beds: implications for the role of the Siberian trap in the Permian-Triassic biotic crisis. Palaeogeogr Palaeoclimat Palaeoecol. 2011;308:22-40.

48. Sadovnikov GN. Evolution of the biome of the middle Siberian Trappean plateau. Palaeontol J. 2016;50(5):518-32.
49. Lozovsky $\mathrm{V}$, Korchagin $\mathrm{O}$. The Permian period ended with the impact of a "Siberia" comet on earth. N Mex Mus Nat Hist. Sci Bull. 2013;60:224-9.

50. Orlova EF. Permian-Triassic conchostracan faunas from the north of Central Siberia. Stratigr Geol Corr. 1999;7:465-72.

51. Malovetskaya IM, Novozhilov NI, Sadovnikov GN. Stages in the development of flora and freshwater fauna in the Tunguska River basin in the late Permian and early Triassic. In: Proc 13th and 14th Sess AllRus Paleontol Soc; 1976. p. 296-300.

52. Aristov DS. New and little known Grylloblattida (Insecta) from intertrappean deposits of the Tunguska basin of Sibiria. Palaeontol J. 2011;5:537-45.

53. Werneburg R. The Permotriassic branchiosaurid Tungussogyrinus Efremov, 1939 (Temnospondyli, Dissorophoidea) from Siberia restudied. Foss Rec. 2009;12:105-20.

54. Brinck P. Revision of the Gyrinidae (Coleoptera) of the Ethiopian region. II Act Univ Lund. 1956:52:1-190.

55. Holger HD. Lehrbuch der Speziellen Zoologie. 5. Teil: Insecta. Berlin: Spektrum Akademischer Verlag; 2003.

56. Ponomarenko AG. Mesozoic gyrinid beetles. Palaeontol J. 1973;4:62-9.

\section{Submit your next manuscript to BioMed Central and we will help you at every step:}

- We accept pre-submission inquiries

- Our selector tool helps you to find the most relevant journal

- We provide round the clock customer support

- Convenient online submission

- Thorough peer review

- Inclusion in PubMed and all major indexing services

- Maximum visibility for your research

Submit your manuscript at www.biomedcentral.com/submit
) Biomed Central 